\title{
Planning for Sustainable Communities: Evaluating Place-Making Approaches
}

\author{
Sanmarie Schlebusch \\ Unit for Environmental Sciences and Management, North-West University, Potchefstroom Campus, South Africa
}

Email address:

24schlebusch@gmail.com

To cite this article:

Sanmarie Schlebusch. Planning for Sustainable Communities: Evaluating Place-Making Approaches. Agriculture, Forestry and Fisheries. Special Issue: Planning for Sustainable Communities: Green-Spaces in Rural Areas. Vol. 4, No. 4-1, 2015, pp. 59-72.

doi: 10.11648 j.aff.s.2015040401.18

\begin{abstract}
People's survival and their quality of life, are irrefutable dependent on the natural environment in which they reside. To ensure that people's quality of life be maintained in any specific area, it is therefore imperative to find a sustainable equilibrium between the social and economic needs of people and the capacity of the natural resources in their environment. The composition of communities is, however, complex and diverse. The multiplicity of culture, gender and age in any particular community, give rise to needs that is unique regarding to that community as well as the impact thereof on the natural environment. For this reason, it will require an ingenious planning approach be followed, whereby the unique needs of people in an specific area as well as the protection of the natural environment simultaneously be addressed. Characteristics of a sustainable community are typically, a healthier, safer, greener, economically independent community which is well managed. Furthermore it has lower transportation costs and less traffic, is more economic in terms of housing and market demands, shows decreased costs of infrastructure and also has low level of air pollution. Place-making, through layout and design, is an integrative planning approach in creating sustainable communities. Place-making is fundamentally a strategy aimed at creating one or more places in an area which, serve as focal points for economic and social activities of people in the community. Such places will contribute to the quality of life in a community and will also encourage more people to visit the area.
\end{abstract}

Keywords: Sustainability, Sustainable Development, Sustainable Communities, Place-Making, Liveability

\section{Introduction}

Sustainability is essential in the process of community planning and plays an important role in the long-term success of communities. Planning for sustainable communities is primarily based on addressing the needs of the people in the community and ensuring a better quality of life. Public participation plays a critical part throughout the process of planning for sustainable communities and in this sense, a sustainable community is created through balancing the environmental, social and economic activities within the community.

Place-making is an integrative approach to the planning and sustainable development of communities. People are attracted to good places with high quality of life, which consist of effective place-making principles that are implemented through layout and design. Good places are a focal point of economic and social activity, thus placemaking approaches can contribute to planning and creating attractive, focal points by including various functions within one space.

According to Giradet a sustainable city [in this instance a community] is planned to enable all of its citizens to meet their own needs and to enhance their wellbeing without damaging the natural world or endangering the living conditions of other people, now or in the future. Planning for sustainable communities is challenging and thus it is essential to compile a framework wherein detailed practical guidelines for implementation of sustainable solutions are described. [1]

Power states that the heart of sustainable development encompasses the simple idea of ensuring a better quality of life for everyone, now and for future generations. It implies meeting the following four objectives simultaneously:

- Social progress which recognizes the needs of everyone;

- Effective protection of the environment;

- Prudent use of natural resources;

- Maintenance of high and stable levels of economic growth and employment; and considering the long-term implications of decisions. [2]

There is a need for an integrated place-making approach 
that will contribute to the planning for sustainability communities of rural and urban areas

\section{Concept of Sustainable Communities}

\subsection{The Language of Sustainability}

Einstein said: "We shall require a substantially new manner of thinking if mankind is to survive." [3]

Jaber, states: "...to create a world that works for all, we need to change the language we use to frame our mindset [4]. Language has real power. It communicates the concepts that shape thought, and, as such, we need to be vigilant about the terms we use". The term "sustainability" in the context of, to provide for, means "the ability to continue into the indefinite future by respecting the Earth's ecosystems, its limits, and providing space for the other beings on the planet to exist [4].

Sustainability is founded on the fundamental principle: "Everything that we need for our survival and wellbeing depends, either directly or indirectly, on our natural environment" [5]. Sustainability creates and maintains the conditions under which humans and nature can exist in productive harmony that permits fulfilling the social, economic and other requirements of present and future generations" [5].

According to Geis \& Kutzmark sustainability is primarily determined by human traditions and practices. The latter, however, are influenced by external factors and may therefore, often change or completely disappear due to the variability of these factors [3]. Geis \& Kutzmark asserts that, limited resources, urbanization, scientific knowledge, technology, social awareness, health and safety imperatives and new economics, are in this regard the main external factors of the twenty-first century. [3]

According to Filho there are many misconceptions regarding the concept of sustainability [6]. Filho is of the opinion that individuals and/or communities opposing sustainability or sustainable development often do not fully comprehend the all-inclusive value and significance of sustainability. These misconceptions usually have a negative impact on the community or society and affect their efforts to work towards a more sustainable future [6]. Perceptions that Filho asserts have a negative influence on society's attitude towards sustainability include:

Sustainability is not a subject per se and it is too theoretical. Notwithstanding sustainability being a high priority in virtually all scientific fields, many continue to view the concept as being vague, without scientific base and expensive to implement. The result is that many see the concept as indistinct and theoretical. Sustainability is too broad and people and institutions are intimidated and discouraged by the scope of the concept, believe the implementation of sustainability difficult to manage and it is too recent a field. Poor knowledge of the significant value of sustainability leads to the unfounded criticism that sustainability merely represents a fashionable trend that only the minority can afford [6].
To eradicate these misconceptions and reservations, Filho suggests that an aggressive informative effort which educates the community extensively on the importance and long-term advantages versus short-term economic sacrifices, simultaneously supported by practical pilot projects and initiatives that illustrate the feasibility of sustainability, will result in individual and collective resolve to pursue sustainable objectives and solutions [6].

\subsection{Sustainable Development}

Berke asserts that the history of the process that was followed in the development as applicable to urban planning of towns, cities and regions has been dominated by the physical design model and the rational planning model, both distinctively representative of a top down approach [7]. This approach permitted government and other major role players the opportunity to manipulate the planning and development process, thereby promoting subjective political and economic objectives and at times overlooking the aspirations and needs of people in specific communities. Since 1960, denunciation of the aforementioned development models mounted as critics progressively exposed the fundamental weaknesses in these models and displeased citizens [7].

The necessity to devise an alternative approach embracing a common goal that would serve the interests of all the people and at the same time protect the environment became noticeably essential [7].

The World Commission on Environment and Development (WCED) of the United Nations was commissioned to conceive a philosophy that will be instrumental to reverse environmental degradation, reduce over-consumption and grind poverty. In their report, Our Common Future, that was published in 1987, portraying the common goal as equity to future generations, the WCED defined the hypothesis of sustainable development as follows: "Sustainable development is development that meets the needs of the present generation without compromising the ability of future generations to meet their own needs" [7].

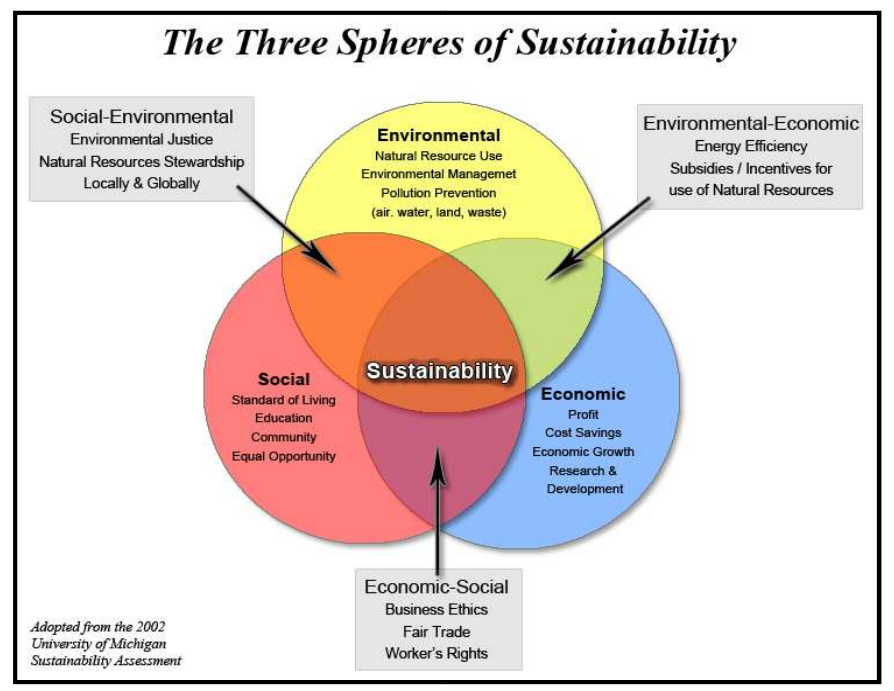

Figure 1. The Three Spheres of Sustainability [8] 
An illustration that examines the three primary values of sustainable development is presented in Figure 1. The expanses where the circles transcend display the core characteristics of sustainable development.

Grasping the aim of the WCED's definition of sustainable development is undemanding, however, translating the concept into procedure shows a diverse interpreting methodology, which is clearly evident in the seven sample definitions of sustainable development below.

Table 1 describes the definitions as provided by The World Commission on Environment and Development (WCED) to capture the essence of sustainable development on a variety of levels.

Table 1. Five examples of definitions for sustainable development [7]

\begin{tabular}{ll}
\hline Level & Definition \\
"Sustainable development respects and defines traditional livelihoods and indigenous culture and societies. It recognizes that communities \\
International & $\begin{array}{l}\text { must define and develop their own solutions to environmental and development problems. It also works toward shared power and } \\
\text { participation, at the local, national, and international levels" (Canadian University Students Organization, 1989: 3). }\end{array}$ \\
& "Our vision is of a life-sustaining Earth. We are committed to the achievement of a dignified, peaceful, and equitable existence. A \\
& sustainable United States will have a growing economy that provides equitable opportunities for satisfying livelihoods and a safe, healthy, \\
high quality of life for current and future generations. Our nation will protect its environment, its natural resource base, and the functions \\
and viability of natural systems on which all life depends" (President's Council on Sustainable Development, 1996: i).
\end{tabular}

Deduced from the multiplicity of the above definitions, it is reasonable to argue that the people and the prevailing circumstances in a specific community, town, region, state or country will determine in what manner the definition of sustainable development should be paraphrased.

The Sustainable Development Commission an independent advisor to the United Kingdom Government on sustainable development, founded six core principles that, from their perspective, determine what sustainable development is and ought to be [2].

Putting sustainable development at the centre Sustainable development must be the organising principle of all democratic societies, underpinning all other goals, policies and processes.

We are and always will be part of nature, embedded in the natural world and very dependent for our own economic and social well-being on the resources and systems that sustain life on earth. Sustainable economic development means 'fair shares for all', ensuring that people's basic needs are properly met across the world, whilst securing constant improvements in the quality of peoples' lives through efficient, inclusive economies [2].

There is no one blueprint for delivering sustainable development. It requires different strategies in different societies. However, all strategies will depend on effective, participative systems of governance and institutions, engaging the interest, creativity and energy of all citizens [2].

Adopting a precautionary approach Scientists, innovators and wealth creators have a crucial part to play in creating genuinely sustainable economic progress. However, human ingenuity and technological power is now so great that we are capable of causing serious damage to the environment or to peoples' health through unsustainable development that pays insufficient regard to wider impacts [2].

Although strategies for the sustainable development of any one community may differ due to different circumstances in the community, strategies should primarily be founded on the principles for sustainable development.

\subsection{Sustainable Communities}

"The sustainable community is a model, an ideal set of goals to work toward. But it also is a philosophy for envisioning those goals and a practical problem-solving process for achieving them" [3]. "A sustainable community seeks to maintain and improve the economic, environmental and social characteristics of an area so its members can continue to lead healthy, productive, enjoyable lives"[5]. The real challenge of creating a sustainable community lies in the process of harmonizing the expectations and needs of the community with the values of sustainability. A sustainable 
community is a community that is economically, environmentally, and socially healthy and strong [10]

To accomplish the process successfully, the fundamental values of sustainability have to form the nucleus of the development and planning approach. [9] A sustainable community underwrites objectives that reflect respect for both the natural environment and human nature [3] A sustainable community should essentially strive to achieve the following characteristics and goals:

Place a high value on quality of life. A sustainable community accepts that communities are first and foremost for people and that the primary objective of the planning and development process is to improve the quality of life of its residents socially, economically, psychologically, and spiritually. It implements policies to achieve quality of life and does so in a fair, open, and democratic manner. [3]

Respect the natural environment. A sustainable community recognizes its relationship to nature and sees nature's systems and components as essential to its wellbeing. It provides access to nature through metropolitan parks, open-space zones, and urban gardens. It understands the sensitive interface between the natural and built environment, develops in a way that will support and complement - not interfere with - nature, and avoids ecological disasters. [3]

Infuse technology with purpose. A sustainable community uses appropriate technology, while ensuring that technology in the built environment is a means to an end, rather than an end unto itself. It emphasizes learning and understanding how existing and new technology can serve and improve communities, not vice versa. It sets clear and measurable goals for what it wants technology to achieve. [3]

Optimize key resources. A sustainable community takes an inventory of its human, natural, and economic resources and understands their finite quality. It ensures that forests are not overused, people are not underemployed, and the places of the built environment are not stagnant and empty. It reduces waste and reuses resources; it creates conditions in which all these resources can be used to their fullest and best potential, without harming or diminishing them. [3]

Maintain scale and capacity. A sustainable community recognizes the importance of scale and capacity with regard to the natural and human environment. It ensures that the environment is not overdeveloped, overbuilt, overused, or overpopulated. It recognizes the signs of tension that indicate when the environment is overstressed and can adjust its demands on the environment to avoid pollution, natural disaster, and social disintegration [3].

"[A] sustainable community reflects the interdependence of economic, environmental, and social issues by growing and prospering without diminishing the land, water, air, natural and cultural resources on which communities depend. Housing, transportation and resource conservation are managed in ways that protect economic, ecological and scenic values" [11].

The Institute for Sustainable Communities views the concept of a sustainable community as a framework to guide action; the following table offers some examples from their experience:

Table 2. The concept of a sustainable community as a framework to guide action [10]

\begin{tabular}{|c|c|}
\hline Example: & Explanation \\
\hline $\begin{array}{l}\text { A Healthy Climate and } \\
\text { Environment }\end{array}$ & $\begin{array}{l}\text { Protection and enhancement of local and regional ecosystems and biological diversity. } \\
\text { Conservation of water, land, energy, and non-renewable resources. } \\
\text { Utilization of prevention strategies and appropriate technology to minimize pollution. } \\
\text { Use of renewable resources no faster than their rate of renewal. } \\
\text { Infrastructure that improves access to services and markets without damaging the environment. }\end{array}$ \\
\hline Social Wellbeing & $\begin{array}{l}\text { Satisfaction of basic human needs for clean air and water and locally sourced nutritious, uncontaminated food. } \\
\text { Affordable provision of quality health prevention, care, and treatment services for all community members. } \\
\text { Safe and healthy housing accessible to all. } \\
\text { Equitable access to quality education services, formal and informal. } \\
\text { The basic human rights of all community members are respected and defended against injustices including exploitation and } \\
\text { psychological and physical harm. } \\
\text { Protection, enhancement and appreciation of community manifestations of cultural diversity, treasures, customs, and traditions. }\end{array}$ \\
\hline Economic Security & $\begin{array}{l}\text { Community members equitably benefit from a strong and healthy community-centred economy. } \\
\text { Diverse and financially viable economic base. } \\
\text { Reinvestment of resources in the local economy. } \\
\text { Maximisation of local ownership of businesses. } \\
\text { Meaningful employment opportunities for all citizens. } \\
\text { Responsive and accessible job training and education programs that enable the workforce to adjust to future needs. } \\
\text { Businesses that enhance community sustainability. }\end{array}$ \\
\hline
\end{tabular}

\subsection{Planning for Sustainable Communities}

"The kind of change required by sustainability implicates each community, each household, and each individual. Successful solutions to problems at this level of society will need to be rooted in the cultural specificity of the town or region if the people are to be supportive of and involved in such change" [12].

Following an eighteen-month investigation, during which contributions of over seventy national, regional and local organizations were scrutinized, the Sustainable Development Commission (SDC) concluded that fundamentally there are 
three aims which, should dominate the development or regeneration approach regarding a sustainable community. These aims are, a healthy environment, a prosperous economy and the social wellbeing of the inhabitants [2].

"Everyone has the right to an environment that is not harmful to their health or wellbeing; and to have the environment protected for the benefit of present and future generations through reasonable legislative and other measures that prevent pollution and ecological degradation as well as promote conservation and secure ecologically sustainable development and use of natural resources while promoting justifiable economic and social development" [13]

\subsection{Conclusion}

The concept of sustainability is more than only a theory. Fundamentally it is a long-term practical solution through which the quality of life of people is prolonged, improved and protected. This outcome can however only be realized, when the basic values, principles and objectives which are intrinsic to the concept, are entrenched in a clearly defined policy which is applicable to all facets of life and that are supported by the community and individuals.

Although the social composition and environmental characteristics, of any one community differs from the other, various place-making approaches had been devised, had been implemented, and could be integrated as building blocks for the planning sustainable communities. Place-making can be managed as it is an approach through which "The Three Spheres of Sustainability" are used to create a better place for people.

\section{Place-Making Approaches}

\subsection{Understanding the Concept of Place-Making}

In his post-World War II speech, Winston Churchill considering the reconstruction of neighbourhoods, communities and buildings, said, "[w]e shape our buildings and then they shape us." [3].

There are many descriptions of the concept of placemaking, such as "both an overarching idea and a hands-on tool for improving a neighbourhood, city or region" Project for Public Spaces, [14] or, according to Placemaking Chicago [15] "the art of creating public 'places of the soul', that uplift and help us connect to each other." It is therefore evident that the concept of place-making cannot be encapsulated by one specific definition, but should rather be understood as a wide range of community strategies and initiatives aimed at the improvement of the community's environment and their quality of [16].

"An effective Placemaking process capitalizes on a local community's assets, inspiration, and potential, ultimately creating good public spaces that promote people's health, happiness, and wellbeing". Thus, place-making is a continuous process, which encapsulate peoples' ideas and through which their needs in terms of the liveability and quality of life are fulfilled by using effective planning, layout and design or redesign of their environment [14].

The Project for Public Spaces asserts that perspectives that were presented by futurists Jacobs and Whyte [17], were the inspiration which eventually gave way to place-making concepts. In her treatise, The Death and Life of Great American Cities, Jacobs proposes ideas, which irrevocably altered planners and activists' approach regarding urban planning. Jacobs) underlines five important perspectives regarding place-making, namely: Cities as Ecosystems, where cities should be viewed as living beings and ecosystems wherein the dynamics of streets, buildings and functions can change in response to human use patterns and related interactions; Mixed Use Development, a diversity of buildings in a city that are used at different times of the day by different genders and age groups to ensure liveliness in the city; Bottom-Up Community Planning - planning for the development of the community, is guided by the community itself and not by other external agendas; The Case for Higher Density, where a high concentration of people is imperative for city life, however, the difference between overcrowding and high density lies in the critical mass of people that are needed to stimulate the community's vitality; and Local Economies, in which case, a city's economy is not dependent on large corporation business, the growth of a city's economy is stimulated by more innovative small business entrepreneurs [17].

A rudimentary objective of the place-making approach is to discover the needs and ambitions of the local community by observing, listening and communicating with the community and subsequently drawing on this knowledge to devise and implement a strategy that effectively fulfils these needs [15] Project for Public formulated eleven (11) principles to direct a strategy towards efficient place-making. These principles are portrayed in Table 3 .

Table 3. Key principles of place-making [15]

\begin{tabular}{ll}
\hline Principles & Explanation \\
\hline The community is the expert & $\begin{array}{l}\text { The community members themselves best communicate the community's needs. } \\
\text { The place-making concept should be fundamental to the layout and design approach. The layout and design are } \\
\text { only the tools. } \\
\text { Identify partners who can contribute in terms of management and innovative ideas and can provide political } \\
\text { and financial support. } \\
\text { "We've never done things that way before." Identify and engage people in the community that share the same } \\
\text { vou can't do it alone }\end{array}$ \\
$\begin{array}{ll}\text { They will always say, "it can't be done" Use the positives and if possible elderly people to help influence the rest of the community. } \\
\text { You can see a lot just by observing }\end{array}$ & \begin{tabular}{l} 
Observing a space enables you to absorb and understand how that specific space is used on a daily basis. \\
\hline
\end{tabular}
\end{tabular}




\begin{tabular}{ll}
\hline Principles & Explanation \\
\hline Develop a vision & The people that use the space effectively should define the vision and character of a space. \\
Form supports function & Existing trends and habits of a specific area should guide the place-making process \\
Triangulate & Identifying elements that are situated next to each other to use in a way that promotes activity. \\
Start with the petunias & $\begin{array}{l}\text { Render small changes and implement progressively. } \\
\text { Combining the location and the level of activity of the public space, with the involvement and willingness of } \\
\text { Money is not the issue }\end{array}$ \\
the partners and local community members can elicit resources from those involved to improve these spaces. \\
You are never finished
\end{tabular}$\quad$\begin{tabular}{l} 
achieved through good management. \\
\hline
\end{tabular}

Thus, place-making as an approach is on-going and driven by the community for the community, facilitated by planners and experts, and takes form in practice through a wellmanaged and effective layout and design approach, which will transform the community and their environment progressively into a place with good living conditions.

\subsection{Criticism on the Place-Making Approach}

There are critics who doubt the conclusive role of placemaking in layout and design approaches for sustainable communities. Grant declares: "We can predict planners to continue to look for the one big theory that can explain all, predict all, and offer guidance for practice to create good communities. We can also safely predict that we are not likely to find such a model" [18].

Critics claims that place-making does not contribute to the development of local economies in previously disadvantaged communities. They assert that place-making only accelerates the gentrification of an area and thereby succeeds in reducing the pressure exerted by the local community and the general public in this regard. If gentrification is primarily projectdriven, development-driven, design-driven or artist-led, this criticism is justified and transformation will only be superficial and limit in terms of the long-term outcome. However, in most instances, this criticism is largely due to ignorance regarding the value and objectives of place-making and confusion as to whom the stakeholders and beneficiaries of the process are [19].

\subsection{Concepts Intrinsic to Place-Making}

From the above definition and description of place-making, it is evident that two concepts are an inextricable part of the place-making approach, namely (1) liveability and (2) lively public spaces, which will be described accordingly.

\subsubsection{Liveability}

The theory of liveability maintains that a person's subjective appreciation of life primarily depends on the objective quality of life. In other words, the better the living conditions in an area or community, the more contented the people living in the area or community will be (Veenhoven $\&$ Ehrhardt, 1995). In turn, the comparison-theory advocates that people in a specific place will be contented if their living conditions are good, irrespective of the knowledge that people living in a different place may experience even better living conditions [20]. People have widespread needs; liveability is the collective arrangement to fulfil these needs. To regard a place as liveable, the collective requirements and demands have to comply with the needs and capacities of individuals. Hence, citizen-centred initiatives should be the principal angle of incidence in conceiving an approach intending to make a place more liveable [20]

Cilliers et al. states that "liveability reflects the wellbeing of a community and comprises the many characteristics that make a location a place where people want to live now and in the future, such as: employment and incomes, community strength, environment, amenity and place, planning, participation, and infrastructure. Economic and community strength are critical to liveability." [21].

Pacione asserts that the relation of people to their everyday environment or living space determines the living conditions in the area and that the prevailing living conditions are a measure of the liveability of the area [22]. Pacione delineates the two fundamental measures of liveability as the cost of living and the quality of life [22].

Economic, social and environmental factors are used when either liveability or quality of life is measured, however, the purpose and the results are different. When the liveability of a place is measured, the objective would be to gauge the liveability characteristics as well as the quality and incidence of services and facilities of a place in terms of these factors. Conversely, when the quality of life is measured, the focus would be to gauge the liveability characteristics and the wellbeing of the inhabitants of a place in terms of these factors. As opposed to quality of life that is primarily being dictated by the subjective experience of people, the liveability of a specific area can be manipulated and influenced through devised policies and layout and design [23].

Although indices of liveability and quality of life is derive from a weighted list of mostly locational characteristics that supposedly contribute to liveability, they are currently used as a benchmarking tool in the evaluation of towns and cities in terms of liveability and quality of life [23].

Table 4: encapsulates fundamental liveability indices currently employed to measure liveability in a city. 
Table 4. Summary of the core liveability indices [21]

\begin{tabular}{|c|c|}
\hline Indices & Measurement \\
\hline \multirow{5}{*}{$\begin{array}{l}\text { Economist Intelligence Unit } \\
\text { Ranks } 127 \text { cities on liveability as part of the Worldwide Cost of Living Survey, } \\
\text { based on five weighted categories (VCEC, 2011:6): }\end{array}$} & 1. Stability $(25 \%)$ - crime and conflict \\
\hline & 2. Healthcare $(20 \%)$ - availability, quality \\
\hline & 3. Culture and environment $(25 \%)$ - climate, recreation, services \\
\hline & 4. Education $(10 \%)$ - availability, quality \\
\hline & 5. Infrastructure $(20 \%)$ - transport, links, housing, utilities, services \\
\hline \multirow{8}{*}{$\begin{array}{l}\text { Mercer human resource survey } \\
\text { The quality of living study has } 39 \text { factors that are grouped into } 9 \text { key categories } \\
\text { (VCEC, 2011:6): }\end{array}$} & 1. Political and social environment \\
\hline & 2. Economic environment \\
\hline & 4. Health and sanitation \\
\hline & 5. Schools and education \\
\hline & 6. Public services and transportation \\
\hline & 7. Recreation, natural environment \\
\hline & 8. Consumer goods \\
\hline & 9. Housing \\
\hline \multirow{5}{*}{$\begin{array}{l}\text { Anholt city brand index } \\
\text { Assesses how people perceive the images of cities, using a survey of nearly } \\
20,000 \text { consumers in } 18-20 \text { countries. Cities are evaluated in terms of: }\end{array}$} & 1. Presence (city's international status and standing) \\
\hline & 2. Place (beauty, climate and other physical attributes) \\
\hline & 4. Pulse (urban appeal and lifestyle) \\
\hline & 5. People (friendliness, openness, cultural diversification and safety) \\
\hline & 6. Prerequisites (basic facilities: hotels, schools, transport, sports) \\
\hline \multirow{10}{*}{$\begin{array}{l}\text { EU Urban Audit } \\
\text { Benchmarking of quality of life in } 58 \text { European cities. Represents the most } \\
\text { comprehensive attempt to assess the liveability and competitiveness of cities } \\
\text { and regions (VCEC, 2011:7). The core issues include: }\end{array}$} & 1. Population, nationality, household structure \\
\hline & 2. Labour market, employment, income disparities, poverty \\
\hline & 3. Housing \\
\hline & 4. Health \\
\hline & 5. Crime \\
\hline & 6. Economic activity, civic involvement \\
\hline & 7. Education and training, level of educational qualifications \\
\hline & 8. Air quality, noise, water, waste management \\
\hline & 9. Land use, travel patterns, energy use \\
\hline & 10. Climate and geography, culture, recreation \\
\hline \multirow{10}{*}{$\begin{array}{l}\text { Global competitiveness index } \\
\text { Developed in 2004, measures national competitiveness in using a weighted } \\
\text { average of factors that contribute to countries competitiveness. The factors are } \\
\text { grouped into twelve categories (VCEC, 2011:13): }\end{array}$} & 1. Institutions \\
\hline & 2. Infrastructure \\
\hline & 5. Further education and training \\
\hline & 6. Goods market efficiency \\
\hline & 7. Labour market efficiency \\
\hline & 8. Financial market sophistication \\
\hline & 9. Technological readiness \\
\hline & 10. Market size \\
\hline & 11. Business sophistication \\
\hline & 12. Innovation \\
\hline \multirow{4}{*}{$\begin{array}{l}\text { Creativity index } \\
\text { Indicator for 'overall standing in creative economy, economic potential' } \\
\text { (Florida 2002), based on four factors: }\end{array}$} & 1. Creative share of workforce (proportion in creative occupations) \\
\hline & 2. High tech industries \\
\hline & 3. Innovation (measured as the number of patents per capita) \\
\hline & 4. Diversity (measured by the number of gay people per capita) \\
\hline
\end{tabular}

Although the combination liveability measures encompassed in the different surveys varies, common factors such as access to infrastructure and services, social equity and cohesion and climatic conditions are included. Notwithstanding fact that the weighting given to each factor is subjective and therefore differs according to the survey [23], it suffices to find the most common used issues of liveability.

It is important to understand that there is a definitive difference between liveability and liveliness.

While liveability is defined in terms of the quality and incidence of services in a place, the liveliness of a place is measured in terms of the frequency and way in which the community takes advantage of the services and facilities available in one place; “... liveliness is entirely associated with people and activities and it can be assessed by measuring pedestrian flows and movements, the uptake of facilities and the existence or otherwise of 'things to do"' [16]. The following section will elaborate on lively public spaces.

\subsubsection{Lively Public Spaces}

The people living in a specific place are the so-called "public", therefore, the focus throughout the process of creating lively public places should primarily be to ensure that the public grounds are accessible and open for a wide range of user groups [24].

The place-making approach is rooted in the principle that a successful public space is also a lively place with distinctive functions that attract a wide variety people. In these lively public spaces, the many functions and activities about community life that take place induce a feeling of ownership 
and connectedness that therefore influence people to stay or return to the place. Lively places can be regarded as spaces with a function [21].

A space signifies the physical and geometrical characteristics of an environment, which, when occupied by people and enhanced by lively elements, are transformed into a place [25].

Great public places have four main key attributes: access and linkages, comfort and image, uses and activities, and sociability. These are evaluated in terms of specific factors within each key attribute that are needed for the space to be regarded as a successful public place [21].

An ordinary place can be transformed into a lively place by augmenting certain key attributes in intangible measurements.

To effectively accomplish the transformation of a space into a lively public place, the public place should be made highly attractive [26] which can be done by including various initiatives such as residential development, educational institutions, open spaces and other facilities [24]. Paul Bevan notes that living, working and playing are ideally much closer together than often found and that, when an area is unlivable, it may be owing to the loss of this proximity [27].

Cilliers et al. assert that norms by which places are evaluated are wide-ranging and common factors that are representative of successful public spaces are not limited to the physical dimensions of a place [21].

Historically, public spaces were places with streets, marketplaces, boulevards, gardens, squares, courtyards, etc., where residents spent a great deal of their time (Loudier \& Dubois, 2001). Present-day traditional planning schemes that are implemented have proved to be somewhat unsuitable to new lifestyles; public places are mostly rather dysfunctional and dehumanized places lacking quality and proper use, and the absence of on-site managers contributes to ineffective public spaces [28].

To create lively public spaces, efforts in the area should focus to render services and opportunities that are versatile, accessible and attractive to a wider range of user-groups and that encourage them to stay. To accomplish this, initiatives such as more residential development, more education institutions in the city centre and attractive facilities and open spaces can be developed [24]. Initiatives such as public transport and roads, arts, entertainment and sporting, social and cultural events may be added [27]. To achieve versatility in an area, alternative uses of the city space should be encouraged [24].

The current physical structure of cities provides for public life, but further opportunities should be developed to strengthen a range of activities within one space in order to create lively city spaces with many benefits.

Place-making is therefore a socially constructed process that shapes spaces by including different functions, aspects and even capital investment, designed to generate economic growth and promote cultural tourism in order to create a place worth living and working in [29].

\subsection{Place-Making Approaches in Urban Planning Context}

"You have to turn everything upside down to get it right side up" [30]. The aforementioned articulates, in essence, the basic principle underlying the bottom-up approach and community-scale of planning.

Place-making was introduced in the urban planning sphere to address community-scale planning with the objective to create qualitative, liveable environments that adhere to the principles of sustainability and progress in the transformation of areas from merely being places that people occupy, socalled ordinary places, into lively places that are good places to live in [16].

The place-making approach can be employed, within the urban planning context, to realize liveability by planning for, and implementing various functions within one space. This can entail the transformation of areas from solely being places that people occupy, into vibrant lively places, by focusing on current public spaces that have potential, and developing these spaces according to the place-making objectives in order to create places with function in which people can socialize and interact [21].

Five place-making approaches include: the livelihoods approach; Power of 10 approach: community participation approach: New Urbanism and Green planning approach. These approaches will be discussed accordingly, as these approaches enable place-making within the rural planning context.

\subsubsection{Livelihoods Approach}

Understanding the diverse needs and activities of people, ingrained in the different ways that different people live in different places, is known as the so-called livelihoods approach [31].

Livelihood can be explained as a prevailing condition that involves capabilities, material and social assets, and activities as a means of living. For this livelihood to become sustainable, it needs to cope with and recover from stresses and shocks; maintain or enhance its capabilities and assets while focusing not to undermine the natural resource base [32].

The sustainable livelihood approach is indicated as a framework that provides an understanding of survival strategies in poor communities and can help to put pro-poor tourism in a better position and guide it towards successful implementation. [33].

The collective term "livelihoods" is considered flexible because of its possible attachment to a number of other phrases such as "...locales (rural or urban livelihoods), occupations (farming pastoral or fishing livelihoods), social difference, (gendered, age-defined livelihoods), directions (livelihood pathways, trajectories), dynamic patterns (sustainable or silent livelihoods) and many more". [32]. Therefore, it is a widely applicable term and is especially relevant when planning for rural areas. The perspectives of livelihoods have been central to rural development thinking and practice in the past decade, and the perspective is rooted in the different ways that different people live in different 
places [32].

Within the livelihoods approach, the focus is on "diversity"e. Fundamental, single-sector approaches to livelihoods and liveability, like that of the comparison [20], have been challenged by this approach in order to address complex rural development problems in a more hands-on and adequate manner [32]. This approach is a simple and straightforward one, as it purely focuses on understanding things (needs, activities, people, etc.) from a local perspective [32]. In order to implement or promote the liveability theory and expand livelihoods accordingly, different aspects should be addressed, including knowledge, politics and scale and dynamics. Portrayed in Table 5 below explains the four above-mentioned perspectives.

Table 5. Perspectives to address

Knowledge
$\begin{aligned} & \text { Livelihoods can be expanded by focusing on inclusive debates about livelihood frameworks and proposed directions of change, } \\ & \text { rather than relying on a bland listing of principles or by keeping questions of values and politics away. }\end{aligned}$
Within these communities, a need for municipal and government services were identified. These needs include an explicit,
theoretically based concern and knowledge of how class, gender and capitalist relations operate. They need to be given the
opportunity and right to actively participate in politics and political discussions by being allowed to ask up front questions regarding
gains and losses based on theories of power and the political economy.
Politics
Scale is an important element to take into consideration when expanding a community's livelihood. Therefore, a livelihood analysis
needs to be developed and implemented. This analysis will examine networks, linkages, connections, flows and chains across
different scales yet will remain in its specific place and context - i.e. rural communities.
Scale
The improvement of livelihoods in terms of dynamics requires local people, policymakers, outsiders, etc., to think about long-term
change. This shift in mind-set can be ensured by providing future strategies and pathways for development and growth.

\subsubsection{Power of 10 Approach}

The Power of 10 place-making approach endorses the concept that an authentic, lively city has at least 10 great public places throughout the city that attract a wide range of user-groups. In these great public places, people are offered many mixed-use opportunities to take pleasure in public life. "And, it's not enough to have one liveable city or town in a region; you need a collection of interesting communities" [15].

A great place offers people opportunities of at least ten (10) things to do or ten (10) reasons to visit the place. For example, a place to sit, art to touch, music to hear, food to purchase, historic information to learn about, and books to read [21]. The opportunities, however, should give expression to the people's experience of the city [15]. "The concept also provides people something tangible to strive for and helps them visualize what it takes to make their community great" [34].

The concept of mixed use and multiple functions in these ten (10) great places should also be dynamic enough to stimulate continuous development and inspire people to come back to the place [15].

Cowan et al. are of the opinion that this type of public place will create lively neighborhoods where interaction arises between people, social gatherings are held and where people simply enjoy spending time [35]. An example of this approach is found in the Canadian city, Toronto, where the focus is placed on combining the rich cultural heritage with creativity. These activities include the Toronto International Film Festival (the largest and arguably the most influential festival in the world); Ontario College of Art and Design; The Young Centre; Wychwood Car Barns and numerous other similar examples [36].

\subsubsection{Community Participation Approach}

"When citizens are effectively engaged in the design process, designers and planners can be at their most effective in facilitating a process that synthesises local experience and wisdom with design principles and technical expertise. Designers can help people uncover their common interests and work towards practical and creative solutions that build local character and assets" [37].

Irrespective of the environmental attributes of an area, the community should be the primary source of information when planning and designing a specific place. Community participation can be seen as an approach to lively planning, or as an indispensable element needed to create a lively place.

However, the composition and dynamics of communities, especially in the urban environment, have become increasingly complex. Cultural diversity, in particular, offers an enormous challenge to public participation; the more diverse the group, the more needs that need to be taken into consideration and therefore the more complex the participation process and input will be [38].

Even though it is difficult to implement, participation remains a critical part of planning for sustainable communities and public places, and the participation of all residents along with supervision, reviews and awareness are important for effective place-making [28]. This qualitative participation approach is needed to address and successfully implement a bottom-up approach, as well as to ensure the planning of functional and usable spaces that can be regarded as lively. To create this type of situation, where active participation is present, it is crucial for the community to play a bigger role in deliberations with authorities, policy formalization and the devising of solutions [21]. 


\subsubsection{New Urbanism Approach}

The planning concept of New Urbanism has been known for some time, however, the implementation thereof only progressively increased since US Congress adopted The Charter of New Urbanism in 1993 that reads as follows: "We advocate the restructuring of public policy and development practices to support the following principals: Neighborhoods should be diverse in use and population. Communities should be designed for the pedestrian and transit, as well as the car. Cities and towns should be shaped by physically defined and universally accessible public spaces and community institutions. Urban spaces should be framed by architecture and landscape design that celebrate local history, climate, ecology and building practices" [39].

The invention and rapid development of the automobile has had a distinct impact on development of cities and towns that was noticeable in the decentralization from the central city. In the 1970 s, while attempting to design a pedestrian based town that is sustainable, USA planners and designers started converting streets into pedestrian walkways as an experiment [40]. Craven declares: "New Urbanist town planners, developers, architects, and designers try to reduce traffic and eliminate sprawl" [40].

"In simplistic, layman's terms, New Urbanism might be defined as taking the most desirable land use and architectural features of communities from the past and adapting them to the technological needs of the present" [39]. basic principles of New Urbanism are explained in Table 6 below.

Table 6. Principles of New Urbanism [41]

\begin{tabular}{|c|c|}
\hline Principle & Explanation \\
\hline Walkability & $\begin{array}{l}\text { Most things within a } 10 \text {-minute walk of home and work. } \\
\text { Pedestrian friendly street design (buildings close to street; porches, windows and doors; tree-lined streets; on-street parking; } \\
\text { hidden parking lots; garages in rear lane; narrow, slow speed streets). } \\
\text { Pedestrian streets free of cars in special cases. }\end{array}$ \\
\hline Connectivity & $\begin{array}{l}\text { Interconnected street grid network disperses traffic and eases walking. } \\
\text { A hierarchy of narrow streets, boulevards, and alleys. } \\
\text { High quality pedestrian network and public realm make walking pleasurable. }\end{array}$ \\
\hline Mixed-Use \& Diversity & $\begin{array}{l}\text { A mix of shops, offices, apartments, and homes on-site. Mixed-use within neighbourhoods, within blocks, and within } \\
\text { buildings. } \\
\text { Diversity of people - of ages, income levels, cultures, and races. }\end{array}$ \\
\hline Mixed Housing & A range of types, sizes and prices in closer proximity. \\
\hline $\begin{array}{l}\text { Quality Architecture \& } \\
\text { Urban Design }\end{array}$ & $\begin{array}{l}\text { Emphasis on beauty, aesthetics, human comfort, and creating a sense of place; special placement of civic uses and sites within } \\
\text { community. } \\
\text { Human scale architecture and beautiful surroundings nourish the human spirit. }\end{array}$ \\
\hline $\begin{array}{l}\text { Traditional Neighbour- } \\
\text { hood Structure }\end{array}$ & $\begin{array}{l}\text { Discernible centre and edge. } \\
\text { Public space at centre. } \\
\text { Importance of quality public realm; public open space designed as civic art. } \\
\text { Contains a range of uses and densities within a 10-minute walk. } \\
\text { Transect planning: highest densities at town centre; progressively less dense towards the edge. The Transect is an analytical } \\
\text { system that conceptualises mutually reinforcing elements, creating a series of specific natural habitats and/or urban lifestyle } \\
\text { settings. The Transect integrates environmental methodology for habitat assessment with zoning methodology for community } \\
\text { design. The professional boundary between the natural and manmade disappears, enabling environmentalists to assess the } \\
\text { design of the human habitat and the urbanists to support the viability of nature. This urban-to-rural transect hierarchy has } \\
\text { appropriate building and street types for each area along the continuum. }\end{array}$ \\
\hline Increased Density & $\begin{array}{l}\text { More buildings, residences, shops, and services closer together for ease of walking, to enable a more efficient use of services } \\
\text { and resources, and to create a more convenient, enjoyable place to live. } \\
\text { New Urbanism design principles are applied to the full range of densities from small towns to large cities. }\end{array}$ \\
\hline Green Transportation & $\begin{array}{l}\text { A network of high-quality trains connecting cities, towns, and neighbourhoods together. } \\
\text { Pedestrian-friendly design that encourages a greater use of bicycles, rollerblades, scooters, and walking as daily trans- } \\
\text { portation. }\end{array}$ \\
\hline Sustainability & $\begin{array}{l}\text { Minimal environmental impact of development and its operations. } \\
\text { Eco-friendly technologies, respect for ecology and value of natural systems. } \\
\text { Energy efficiency. } \\
\text { Less use of finite fuels. } \\
\text { More local production. } \\
\text { More walking, less driving. }\end{array}$ \\
\hline Quality of Life & $\begin{array}{l}\text { Taken together, these add up to high quality of life well worth living, and create places that enrich, uplift and inspire the } \\
\text { human spirit. }\end{array}$ \\
\hline
\end{tabular}


Thus, New Urbanism is an urban planning approach, which provides for the implementation of place-making principles through which the urban environment is transformed into an integrated, compact, walkable, mixeduse, vibrant and sustainable community where people experience high quality of life.

\subsubsection{Green Planning Approach}

The widely accepted definition of urban green spaces is that they are "public and private open spaces in urban areas, primarily covered by vegetation, which are directly (e.g. active or passive recreation) or indirectly (e.g. positive influence on the urban environment) available for the users" [42].

Unplanned development and urbanization patterns, especially in cities, have had a negative influence on green spaces that consequently resulted in a significant decrease in the environmental benefits of green [43]. "If green spaces are so important for human wellbeing, how is it possible to increase these areas and maximise the positive aspects for humans, while at the same time decrease the negative aspects of cities for the environment?" [44].

Green spaces play a key role in the sustainable development of communities and likewise contribute decisively to the liveability of the built-up environment. Green spaces have a direct link to place-making and add quality to a place. The character of a community is often identified and labeled by the quality of its green spaces. Well designed, efficiently managed and maintained green spaces enhance living and working conditions, has social and visual value and, equally importantly, attract people and investment into an area [45].

Development of green spaces is an integrated approach to sustainable environments and plays an important role in terms of social, economic, cultural and environmental aspects of sustainable development [42]. A strategy for green spaces has to effectively and concurrently address a variety of (ecological) environmental, social, economic and sustainable development issues [46].

Green planning approaches of countries, cities and communities may be at variance, however, the central focus should underwrite the place-making concept and conclusively achieve transformation of a space into a lively public place. Therefore, a Green planning approach should include objectives such as: to safeguard the future of green spaces; to enhance the quality of urban areas; to render urban areas more attractive and thereby attract more resources; and to enhance the wellbeing of the user-group [46].

Benefits derived from an effective Green planning approach can be categorized according to three main groups, including: environmental benefits, economic and aesthetic benefits and social and psychological benefits [42]. These are discussed briefly in the table below.

Table 7. Environmental Benefits of Urban Green Spaces [42]

\begin{tabular}{ll}
\hline Environmental Benefits \\
\hline Ecological Benefits & $\begin{array}{l}\text { Urban green spaces supply cities with ecosystem services ranging from maintenance of biodiversity to the regulation } \\
\text { of urban climate. }\end{array}$ \\
& $\begin{array}{l}\text { Pollution in cities is due to pollutants which include chemicals, particulate matter and biological materials, which } \\
\text { occur in the form of solid particles, liquid droplets or gases. }\end{array}$ \\
Air and noise pollution is common phenomenon in urban areas. The presence of many motor vehicles in urban areas \\
produces noise and air pollutants such as carbon dioxide and carbon monoxide. Emissions from factories, such as \\
sulphur dioxide and nitrogen oxides, are very toxic to both human beings and the environment. \\
Green spaces function as protection centres for the reproduction of species and conservation of plants, soil and water \\
quality. Urban green spaces provide the linkage of the urban and rural areas. They provide visual relief, seasonal \\
change and a link with the natural world. \\
A functional network of green spaces is important for the maintenance of ecological aspects of a sustainable urban \\
landscape, with greenways and use of plant species adapted to the local condition with low maintenance cost, self- \\
sufficiency and sustainability
\end{tabular}

Table 8. Economic and Aesthetic Benefits of Urban Green Spaces [42]

\begin{tabular}{ll}
\hline Economic and Aesthetic Benefits \\
\hline Energy Savings & $\begin{array}{l}\text { Using vegetation to reduce the energy costs of cooling buildings has increasingly been recognised as a cost effective reason for } \\
\text { increasing green space and tree planting in temperate climate cities. Plants improve air circulation, provide shade and they } \\
\text { evapotranspire. This provides a cooling effect and helps lower air temperatures. A park of } 1.2 \mathrm{~km} \text { by } 1.0 \mathrm{~km} \text { can produce an air } \\
\text { temperature between the park and the surrounding city that is detectable up to } 4 \mathrm{~km} \text { away. A study in Chicago has shown that increasing } \\
\text { tree cover in the city by } 10 \% \text { may reduce the total energy for heating and cooling by 5\% to } 10 \% .\end{array}$ \\
$\begin{array}{l}\text { Areas of the city with enough greenery are aesthetically pleasing and attractive to both residents and investors. The beautification of } \\
\text { Singapore and Kuala Lumpur, Malaysia, was one of the factors that attracted significant foreign investments that assisted rapid } \\
\text { economic growth. Still, indicators are very strong that green spaces and landscaping increase property values and financial returns for } \\
\text { land developers of between 5\% and } 15 \% \text {, depending on the type of project. }\end{array}$ \\
\hline
\end{tabular}


Table 9. Social and Psychological Benefits of Urban Green Spaces [42]

\begin{tabular}{ll}
\hline & Social and Psychological Benefits \\
\hline Recreation and & $\begin{array}{l}\text { People satisfy most of their recreational needs within the locality where they live. Findings by Nicol and Blake (2000) show that over } \\
\text { Wellbeing }\end{array}$ \\
& $\begin{array}{l}\text { outdoor leisure opportunities. } \\
\text { The level of stress in people who were exposed to natural environments decreased rapidly compared to people who were exposed to }\end{array}$ \\
& $\begin{array}{l}\text { urban environments, whose stress levels remained high. In the same review, hospital patients whose rooms were facing a park had a } \\
10 \% \text { faster recovery rate and needed } 50 \% \text { less strong pain relieving medication compared to patients whose rooms were facing a } \\
\text { building wall. } \\
\text { This is a clear indication that urban green spaces can increase the physical and psychological wellbeing of urban citizens. In other } \\
\text { research conducted in Swedish cities, people who spent more time outdoors in urban green spaces were less affected by stress. } \\
\text { Certainly, improvements in air quality due to vegetation have a positive impact on physical health, with such obvious benefits as a } \\
\text { decrease in respiratory illnesses. The connection between people and nature is important for everyday enjoyment, work productivity } \\
\text { and general mental health. }\end{array}$ \\
\hline
\end{tabular}

It is thus evident that, depending on the dominant conditions of a place, development of green spaces may present many challenges. Nevertheless, through careful planning and site-responsive design, urban green spaces can make a meaningful contribution to sustainable development at regional, district and local levels. The planning of layout and design approaches for rural green spaces should strive to meet the needs of the community, optimize opportunities in the community to grow towards sustainability, and furthermore contribute to the specific character and image of a place and the community. Uncomplicated access to green spaces will benefit these efforts and stimulate physical activity.

\subsubsection{Conclusion of Place-Making Approaches in Planning Context}

The main objective of the place-making concept is the improvement of the community's environment and their quality of life [16].

In order to evaluate the contribution of the three placemaking approaches in planning sustainable communities, it is necessary to evaluate these approaches in terms of the Three Spheres of Sustainability Table 1 illustrates this evaluation.

Table 10. Place-making approaches in the context of sustainability

\begin{tabular}{|c|c|c|c|}
\hline \multirow{2}{*}{ Approach } & \multicolumn{3}{|c|}{ Three Spheres of Sustainability } \\
\hline & Social & Environmental & Economic \\
\hline Livelihoods approach & $\nabla$ & $\nabla$ & \\
\hline Power of 10 approach & $\square$ & & $\nabla$ \\
\hline $\begin{array}{l}\text { Community participation } \\
\text { approach }\end{array}$ & $\nabla$ & $\nabla$ & $\nabla$ \\
\hline New Urbanism approach & $\nabla$ & & $\square$ \\
\hline Green planning approach & $\nabla$ & $\nabla$ & $\nabla$ \\
\hline
\end{tabular}

From the above evaluation, it is evident that place-making is a concept that can be used to change and improve the spaces and places within communities. In the rural planning context, place-making, built fundamentally on various lively and sustainable objectives, can act as a catalyst to affect the planning for sustainable communities.

\section{Conclusion}

In conclusion, continuous monitoring of the implementation and progress of place-making approaches is imperative. Therefore, transparent management and evaluation of an approach should be maintained to ensure that effectual amendments are made timeously when deemed mandatory. Equally important is that legislation, policies and guidelines that regulate and manages place-making approaches should at all times endeavour to harmonise the needs of the community with the natural layout and resources of the environment, thereby ensuring an effective and sustainable design.

\section{Acknowledgements}

This research (or parts thereof) was made possible by the financial contribution of the NRF (National Research Foundation) South Africa.

Any opinion, findings and conclusions or recommendations expressed in this material are those of the author(s) and therefore the NRF does not accept any liability in regard thereto.

\section{References}

[1] H. Girardet. Creating Sustainable Cities. Dartington: Green Books, 1999.

[2] A. Power. Sustainable communities and sustainable development: a review of sustainable communities. 2004. http://eprints.1se.ac.uk/28313/1/CASEreport23.pdf

[3] D. Geis, and T. Kutzmark. Developing Sustainable Communities: the future is now. 2006. $\mathrm{http}: / /$ freshstart.ncat.org/articles/future.htm

[4] D. Jaber .The Language of Sustainability: why words matter. 2009. http://www.greenbiz.com/blog/2009/11/18/languagesustainability-why-words-matter

[5] United States Environmental Protection Agency. Action Planning and the sustainable Community. 2012. http://www.epa.gov/greenkit/sustain.htm

[6] W.L. Filho. Dealing with misconceptions of the concept of sustainability.

2000 . http://www.esd.leeds.ac.uk/fileadmin/documents/esd/2._Intern ational_Journal_of_Sustainability_in_Higher_Education_2000

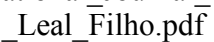


[7] P.R. Berke. Does Sustainable Development Offer a New Direction for Planning? Challenges for the Twenty-First Century. http://arroyofilms.com/ftpuser/2nd\%20wknd/Berke.pf

[8] Vanderbilt University Sustainability and Environmental Management Office.. What is Sustainability? 2013. http://www.vanderbilt.edu/sustainvu/who-we-are/what-issustainability/

[9] Peter, C. \& Swilling, M. 2012. Sustainable, Resource Efficient Cities - Making it Happen! http://www.greengrowthknowledge.org/resource/sustainableresource-efficient-cities-\%E2\%80\%93-making-it-happen Date of access: 22 May 2013.

[10] Institute for Sustainable Communities.. What is a Sustainable Community? 2014 http://www.iscvt.org/what_we_do/sustainable_community/

[11] Natural Resources Defense Council. Sustainable Communities. 2012. http://www.nrdc.org/sustainable-communities/

[12] Teaching and Learning for a Sustainable Future. Sustainable Communities. 2010 http://www.unesco.org/education/tlsf/mods/theme_c/mod17.ht $\mathrm{ml}$

[13] United Nations (UN). Economic aspects of sustainable development in South Africa. 1997. http://www.un.org/esa/agenda21/natlinfo/countr/safrica/eco.ht $\mathrm{m}$

[14] Project for Public Spaces. What is Placemaking? 2011a. http://www.pps.org/reference/what_is_placemaking/.

[15] Placemaking Chicago. What is placemaking? 2008. http://www.placemakingchicago.com/about/

[16] M. Lamit, A. Ghahramanpouri, and S . Sedaghat Nia. A Behavioral Observation of Street Liveliness in Meldrum Walk, Johor Bahru of Malaysia. 2012. http://tuengr.com/V04/003014.pdf

[17] J. Jacobs. Placemakers. 2011 http://archigar.blogspot.com/2011/02/placemakers-janejacobs.html

[18] J. Grant. Planning the Good Community. 2006. http://www.tandfonline.com/doi/abs/10.1080/1464935080266 683\#.U0VWzfmSx3k

[19] Project for Public Spaces. All Placemaking is Creative: how a shared focus on place builds vibrant destinations. 2013. http://www.pps.org/blog/placemaking-as-communitycreativity-how-a-shared-focus-on-place-builds-vibrantdestinations/

[20] R. Veenhoven, and J. Ehrhardt. The cross-national pattern of happiness: test of predictions implied in three theories of happiness. 1995. Social Indicators Research, 34:33-68.

[21] E.J .Cilliers, W. Timmermans, F. Van den Goorbergh, and J.S.A. Slijkhuis, The Lively Cities (LICI) background document: LICI theory and planning approaches. Part of the LICI project (Lively Cities, made possible by INTERREG IVB North West Europe, European Regional Development Fund, European Territorial Cooperation, 2007-2013. Wageningen University of Applied Sciences, Van Hall Larenstein).
[22] M. Pacione. Urban Geography: A global perspective. 2005. 2nd ed. New York: Routledge.

[23] VCEC. 2011. VCEC Regulatory Conference. 2011. http://www.vcec.vic.gov.au/CA256EAF001C7B21/pages/vcec -regulatory-conference-2011\#.UuUo6fu6Jdg

[24] Hobart City Council.. Hobart .Public Spaces and Public Life, a city with people in mind. 2010 http://www.hobartcity.com.au/Hobart/A_City_with_People_in _Mind

[25] S. Harrison and P. Dourish, Re-place-ing space: the roles of place and space in collaborative systems. 1996. http:/www.dourish.com/publications/1996/cscw96-place.pdf

[26] H. Soholt, Life, spaces and buildings - turning the traditional planning process upside down. 2004. http://www.walk21.com/papers/Copenhagen $\% 2004 \% 20$ Soholt $\% 20$ Life $\% 20$ spaces $\% 20$ and $\% 20$ buildings $\% 20$ turning\%20the $\% 20 t . p d f$

[27] The Economist Intelligence Unit. Liveable Cities: challenges and opportunities for policymakers. 2010. https://www.europeanvoice.com/GED/00020000/22400/22491 .pdf

[28] C. Loudier and J.L Dubois. Public spaces: between insecurity and hospitality. 2001. http://www.ocs.polito.it/biblioteca/verde/uk_PARTIE201_C13 3.134.pdf

[29] K.F. Lanham, Planning as placemaking: tensions of scale, culture and identity. Blacksburg, Vancouver: Virginia Polytechnic Institute and State University. 2007.

[30] Project for Public Spaces. The Atlantic Interviews Fred Kent. 2011b. http://www.pps.org/blog/the-atlantic-interviews-fredkent/

[31] R. A. Williams, Environmental Planning for Sustainable Urban Development. 2000 http://www.bvsde.paho.org/bvsaidis/cwwa9/will.pdf

[32] I. Scoones. Livelihoods perspectives and rural development. 2009. Journal of Peasant Studies, 36(1):1-26.

[33] R. LeGates and , F. Stout. A Short History of Urban Planning. 2013. www.docslide.com/a-short-history-of-urban-planning/

[34] Project for Public Spaces. Transforming Cities through Placemaking and Public spaces. 2012. http://www.urbangateway.org/sites/default/ugfiles/Transformi ng\%20Cities\%20Through\%20Place\%20Making_\%20PPS_Cy nthia\%20Nitikin.pdf

[35] S. Cowan, M. Lakeman, J. Leis, D. Lerch, and J.C. Semenza. The City Repair Project. 2006. www.inthefield.info/city_repair.pdf

[36] Toronto. Creative city planning framework: a supporting document to the agenda for prosperity: prospectus for a great city. Toronto: AuthentiCity. 2008.

[37] A. McBride. Community Wisdom + Expert Knowledge $=$ Good Community Design. 2013 http://www.pps.org/blog/community-wisdom-expertknowledge-good-community-design/

[38] B. Breman, M. Pleijte, S. Ouboter, and A. Buijs, Participatie in waterbeheer. Een vak apart. 2008. http://www.levenmetwater.nl/static/media/files/Praktijkhandlei ding participatie in het waterbeheer.pdf 
[39] R. Thornton. What is New Urbanism? - Part 1. , 2010. http://www.examiner.com/article/what-is-new-urbanism-part1

[40] J. Craven. What is New Urbanism? 2013. http://architecture.about.com/od/communitydesign/g/newurba n.htm

[41] Michigan Land Use Institute. 10 Principles of New Urbanism 2006. http://www.mlui.org/mlui/news-views/articles-from1995-to-2012.html?archive_id=678\#.UzP64fmSx3k

[42] S.M.A. Haq. Urban green spaces: an integrative approach to sustainable environment. 2011. http://www.scirp.org/journal/PaperInformation.aspx?paperID= 5881\#.Ut FThD8LIU

[43] C. S. Gomes and E.M. Moretto. A framework of indicators to support urban green area planning: a Brazilian case 2011. study.http://www.iaees.org/publications/journals/piaees/article s/2011-1(1)/A-framework-of-indicators-to-support-urban.pdf

[44] J. Schilling. Towards a Greener Green Space Planning. 2010. http://www.lumes.lu.se/database/alumni/08.10/Thesis/Schillin g_Jasper_Thesis_2010.pdf

[45] T. Baycan-Levent and P. Nijkamp, Urban Green Space Policies : a comparative study on performance and success conditions in European cities. 2004 http://dare2.ubvu.vu.nl/bitstream/handle/1871/8932/20040022 .pdf? sequence $=1$

[46] H.D. Kasperidus, I.S. Erjavec, M. Richter, C.S Costa, B. Edlich. B.Guideline for the General Procedure of Developing and Implementing an Urban Green Space Strategy. 2006. http://www.greenkeysproject.net/media/files/greenkeys_strategy_guideline.pdf 